\title{
Molybdenum and potassium in the foliar fertilization and seed quality in the soybean
}

\author{
Rafael Tissot Frota ${ }^{1}$, Ivan Ricardo Carvalho ${ }^{1, *}{ }^{(0}$, Murilo Vieira Loro ${ }^{1}{ }^{\circ}$, Gustavo Henrique

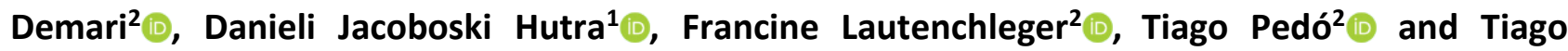 \\ Zanatta Aumonde ${ }^{2}$ (B) \\ 1 Universidade Regional do Noroeste do Estado do Rio Grande do Sul. Rua do Comércio, 3000, CEP 98700-000 - Universitário, ljuí, RS, \\ Brazil. 2Universidade Federal de Pelotas, Departamento de Fitotecnia - Avenida Eliseu Maciel, CEP - 96160000 - Capão do Leão, RS, \\ Brazil. *Corresponding author: ivan.carvalho@unijui.edu.br
}

\begin{abstract}
Molybdenum is the micronutrient required in less quantity by plants and found in lower concentrations in Brazilian soils. The study aimed to study the influence of the application of molybdenum (Mo) and potassium (K) via foliar feeding, at different phenological stages, on the quality of soybean seeds. The work was conducted in the field in the county of Coronel Bicaco, RS under the condition of a typical dystropheric red Latosol (Oxisol) soil, in the 2017/2018 season crop. The experimental design was randomized blocks in a factorial scheme phenological stages $x$ cultivars. Analysis of variance revealed significance for the interaction between phenological stages $x$ cultivars for the variables composed by germination, abnormal, hard, dead, as well as field emergence, plant length and root length. There is influence of foliar feeding of molybdenum (Mo) and potassium (K) in different phenological stages of soybean. It was found that there was no significant difference for the yield of soybean cultivars under foliar feeding of Mo and $K$ in the different treatments to which they were submitted.
\end{abstract}

Keywords: Seed production, management of crops, nutrients, soybean nutritional needs, plant nutrition, symbiotic fixation of nitrogen.

\section{INTRODUCTION}

Soybean (Glycine max L. Merrill) has economic relevance in Brazilian agriculture, both for the area sown and for the production of grains, making Brazil the largest exporter of soybean in the world, this is due to increased productivity, a consequence of breeding and the improvement of management practices. Brazil stands out in the production of soybeans, being currently the second largest world producer, behind only the United States, with production in the 2016/17 crop of 114 million tons, and for the 2018/19 crop there is the projection of 117 million tons (Companhia Nacional de Abastecimento [CONAB], 2018).

In order to increase and maintain yield, it is necessary to use high quality seeds. The quality of the seed reflects directly on the initial establishment of the crop, generating seedlings of greater vigor, able to better withstand abiotic stresses and make better use of environmental resources.

Among the alternatives for the maintenance and improvement of the physiological quality of the seeds, the association of products can increase the productivity of the crop, as well as increase the quality of the seeds produced. However, there are few studies that show the associated effect of applications in different phenological stages of soybeans, because for a thorough study on the expression of genetic potential, it is necessary to make observations at various phenological stages of the plant. Meneghette et al (2019) point out that recent studies demonstrate that potassium fertilization in areas suitable for the no-till system, results in a good correlation with the production of cover phytomass used in the rotation process.

Phenological stages are characterized by the development of the soybean plant during the cycle. The methodology for describing the stages of development proposed by Fehr and Caviness (1977) is the most used worldwide, being divided into the vegetative $(V)$ and reproductive $(R)$ development stages, followed by numerical indices that identify specific stages, however, for the stages "VE" which represents emergency and "VC", which represents cotyledon.

Several factors influence the achievement of high productivity in the soybean crop, among which stands out the adequate supply of nutrients, which is provided to plants by the practice of fertilization. The nutritional needs of any plant are determined by the amount of nutrients extracted during the cycle. Thus, 
it is necessary that these are available in the quantities necessary for the plants (Matsumoto et al., 2017; Santinoni et al., 2019).

According to Korber, Pinto, Pivetta, Albrecht and Frigo (2017), soybean needs several nutrients to develop, with potassium $(\mathrm{K})$ being the second most exported nutrient for soybean crop. On average, around $18.5 \mathrm{~kg}$ of $\mathrm{K}$ per ton of grain produced is exported. $\mathrm{K}$ deficiency in the soil can not only cause severe visible deficiency in plants, but this deficiency will directly affect the productivity and quality of grains (Serafim, Ono, Zeviani, Novelino, \& Silva 2012). This nutrient is essential in almost all the processes necessary for plant life, performing vital functions such as opening and closing stomata, transporting carbohydrates and other compounds, in addition to activating many enzymes involved in respiration and photosynthesis (Taiz \& Zeiger, 2012).

Molybdenum is the micronutrient required in less quantity by plants and found in lower concentrations in Brazilian soils. It plays a fundamental role in plant nutrition, as its function is related to nitrogen metabolism and is part of two metalloenzymes: nitrogenase, which participates in the symbiotic fixation of nitrogen and nitrate reductase, which acts in reducing nitrate to ammonia in plant (Broadley, Brown, Cakmak, Rengel and Zhao 2011).

According to Diesel et al., (2010) the efficiency of the biological N2 fixation process, as well as its metabolism, can be impaired by molybdenum (Mo) deficiency, as this is part of the nitrate reductase and nitrogenase enzymes. Due to its importance in the biological nitrogen fixation process, Mo is one of the micronutrients required by soybeans, which presents the most frequent and consistent response in productivity, even though it is not exported in a large quantity by the crop.

Currently, alternatives are being sought to improve the quality of seeds, which revert to more vigorous plants, and consequently greater productivity. In this sense, the study aimed to study the influence of the application of molybdenum (Mo) and potassium (K) via foliar feeding, at different phenological stages, on the quality of soybean seeds.

\section{MATERIALS AND METHODS}

The work was conducted in the field in the county of Coronel Bicaco, RS, on the property of Mr Harold Krüger, under the condition of a typical dystropheric red Latosol (Oxisol) soil, in the 2017/18 season crop. Four soybean cultivars were used, NS 5727 IPRO medium cycle (122-132 days) belonging to the maturity group 5.7, with an indeterminate growth habit, cultivar DM 5958 IPRO medium cycle (125-133 days) belonging to the maturity group 5.8, with indeterminate growth habit, cultivar NA 5909 RG medium cycle (125-135 days) belonging to the maturity group 6.2 indeterminate growth habit, cultivar NS 5959 IPRO medium cycle (123-133 days) belonging to the maturity group 5.9 with indeterminate growth habit. Sowing was carried out on December 7, 2017 and the harvest on April 18, 2018.

Before sowing the seeds were treated with insecticide Thiamethoxan $350 \mathrm{~g} . \mathrm{L}^{1}$ in the dose of $200 \mathrm{ML} 100$ $\mathrm{kg}^{-1}$ of seed, and of fungicide Fluodioxonil $25 \mathrm{~g} \mathrm{~L}^{1}+$ Metalaxil-M $10 \mathrm{~g} \mathrm{~L}^{1}$ in the dose of $100 \mathrm{~mL} 100 \mathrm{~kg}$ of seed. In addition, inoculated with peat with $5 \times 10$ rhizobia per milligram in the dose of $100 \mathrm{~g} / 50 \mathrm{Kg}^{-1}$ of seed. The control of weeds, pests and diseases was carried out with products recommended for soybean growing, according to the needs. Sowing was with a tractor fertilizer sowing machine equipped with seed metering mechanisms, with nine sowing lines spaced $0.50 \mathrm{~m}$ apart and under black oats (Avena Sativa L.) coverage under no-tillage system. The basic fertilization was $250 \mathrm{~kg}^{-1}$ of fertilizer 02.23 .23 . The experimental unit consisted of 11 plots with dimensions of 3 meters wide by 18 meters long, totaling $54 \mathrm{~m}^{2}$ per plot.

The experimental design was randomized blocks in a factorial scheme phenological stages $\mathrm{x}$ cultivars, with 3 replications as shown in table 1 . The products used in the experiment were Mo $15 \%$ density $1.4 \mathrm{~g} \mathrm{~cm}^{3}$ at a dose of $100 \mathrm{~mL} \mathrm{ha}^{-1}$ and $\mathrm{K} 35 \%$ density $1.5 \mathrm{~g} \mathrm{~cm}^{3}$ at a dose of $1.0 \mathrm{~L} \mathrm{ha}^{-1}$, with foliar feeding at the time that the plants reached their determined phenological stages. The foliar application of the products used an electric backpack sprayer with a flow rate of $100 \mathrm{~L} /$ ha ${ }^{1}$ of spray mixture and a bar with 4 nozzles with a spacing of $0.5 \mathrm{~m}$.

The harvest was carried out at the moment when the crop reached its harvest maturation stage with less than $13 \%$ moisture in the seed, each plot was manually cut one meter long by four lines wide, totaling two square meters of harvested area. The harvested material was tracked manually, afterwards they were processed in an air machine and sieve and spiral, after the processing of the seeds they were submitted to post-harvest evaluations. Yield was determined by harvesting the useful area of the plot, correcting the moisture content to $13 \%$ and transforming it to one hectare. 
- Yield: to determine the yield, the useful area of each plot was collected, the grains were cleaned, the impurities were removed and the grains were then weighed to obtain the final result.

Table 1. Treatments applied in the experiment containing Molybdenum (Mo) and Potassium (K) with the respective phenological stages and product dose.

\begin{tabular}{cccc}
\hline Treatment & Product & Phenological stage & Dose/Product Ha \\
\hline 1 & Mo & V3 & $100 \mathrm{~mL}$ \\
2 & Mo & R1 & $100 \mathrm{~mL}$ \\
3 & Mo & GF & $100 \mathrm{~mL}$ \\
4 & Mo & V3 - R1 & $100 \mathrm{~mL}$ \\
5 & Mo & V3 - R1 - GF & $100 \mathrm{~mL}$ \\
6 & K & R1 & 1,01 \\
7 & K & GF & 1,01 \\
8 & Mo + K & V3 - R1 & $100 \mathrm{~mL}+1,01$ \\
9 & Mo+k+k & V3 - R1 - GF & $100 \mathrm{~mL}+1,01$ \\
10 & Mo+Mo+k+k & V3 - GF - R1 - GF & $100 \mathrm{~mL}+1,01$ \\
Control & & & \\
\hline
\end{tabular}

- Germination: eight subsamples with 50 seeds were used for each treatment, sown in a germitest paper roll, moistened with a volume of water 3 times the mass of the dry substrate and maintained in a BOD type germination chamber at $25^{\circ} \mathrm{C}$ and a photoperiod of 12 hours. The counts were performed at five and eight days after sowing, according to the Rules for Seed Analysis and the results will be expressed as a percentage of normal plants.

- Seedling length: four subsamples were collected with ten normal seedlings at random per treatment and measured with the aid of a ruler. The test was carried out at eight days after sowing. The results were expressed as the individual seedling average in $\mathrm{mm}$ seedling ${ }^{-1}$.

- Accelerated aging: conducted as described by using gerbox, with a $40 \mathrm{~mL}$ water slide, the seeds being placed on a screen positioned above the water slide, kept in an oven at $42{ }^{\circ} \mathrm{C}$, for 36 hours. After this period, the germination test was performed, with four sub-samples of 50 seeds per treatment, counting eight days after sowing, according to the criteria established in the Rules for Seed Analysis.

The data obtained were subjected to analysis of variance at $5 \%$ probability where to verify the assumptions of the statistical model. Subsequently, the interaction between phenological stages $\mathrm{x}$ cultivars was tested at $5 \%$ probability. When identifying significance to the interactions, they were broken down to simple effects.

\section{RESULTS AND DISCUSSION}

Analysis of variance revealed significance for the interaction between phenological stages $\mathrm{x}$ cultivars for the variables composed by germination, abnormal, hard, dead, as well as field emergence, plant length and root length. In Table 2, it is possible to observe the averages for the interaction of application times by cultivars, for the variables germination, abnormal seeds, hard and dead. The cultivar NS 5727 and the control with the application of potassium via foliar in Grain Filling (GF) showed higher germination values, as well as in cultivar DM 5958 the use of molybdenum in R1 (T2). The cultivars NA 5909 and NS 5959 when submitted to the application of Mo only in V3 (T1) presented lower germination values.

In table 2, the results for the abnormal seedlings were also analyzed, and the cultivar NS 5959 presented a greater or equal amount of abnormal plants among the other cultivars. It was also possible to notice that the cultivar NA 5909, was the cultivar that presented less or equal abnormality when compared with the other cultivars. Relevant to hard seeds, evaluated from the accelerated aging test, it was found that the cultivar NS 5727 stood out among the other cultivars in treatment 5 and for the other cultivars there was no significant difference between them. Looking at table 3, it appears that related to the germination of dead seedlings, the cultivar NS 5727 was the one that showed the highest amount in most treatments except for the control and 9 (Mo V3 KR1 KGF). 
Table 4 shows the results obtained for accelerated aging. The cultivar NS 5959 presented the highest percentage of abnormal seedlings when compared to the cultivars analyzed among all treatments. In this same cultivar (NS 5959), under the same analysis it was also possible to observe the high percentage of dead seedlings. According to Soares et al. (2015) and Felisberto et al. (2015), the cultivars have different characteristics in terms of genetic background, growth habit, maturity group and other attributes, allowing for the existence of variations, highlighting the importance of carrying out, above all, field trials in different locations.

Looking at table 4, the results for accelerated aging can be seen. The cultivar NS 5727, the control and treatment 5 were superior to the other treatments for this cultivar, whereas the cultivar DM 5958 in treatments $1,2,3,4,6$ and 7 , were those that presented the highest germination percentage in the accelerated aging test compared to other treatments, where the vigor of the seeds is significantly influenced by potassium doses, regardless of the dose and method of application.

The cultivar NA 5909 in treatments 1, 3, 4, 6 and 7 obtained a higher percentage of germination in accelerated aging, when compared to the other treatments. However, cultivar NS 5959 was the cultivar that obtained the lowest results in accelerated aging for treatments 9 and 10. Veiga et al. (2010) observed that increasing potassium doses do not influence soybean seed germination, and that after seed aging, higher vigor values were found in seeds produced in an area with $85 \%$ base saturation, reaching values of $97 \%$ of vigor. This result also corroborates with that reported by Struker et al. (2019), according to which, the response to mineral nutrition may be conditioned to the genotype. Fonseca and Sá (2005) studying the physical and physiological quality of seeds of two soybean cultivars as a function of potassium and limestone doses, also concluded that the cultivars showed different behaviors.

In studies by Nakao et al (2014) the length of seedlings also increased with the use of increasing doses of molybdenum, which indicates that the micronutrient leaf spray interferes with the vigor of the harvested seed. In the case of fertilization with K, Veiga et al (2010), when using the germination and accelerated aging tests, did not verify effect of the application of up to $200 \mathrm{~kg} \mathrm{ha}^{-1}$ of $\mathrm{K}_{2} \mathrm{O}$ on the quality of soybean seeds. Toledo et al. (2011), however, reported that the application of up to $100 \mathrm{~kg} \mathrm{ha}^{-1}$ of $\mathrm{K}_{2} \mathrm{O}$ results in an increase in seed germination without, however, affecting the vigor, assessed by the electrical conductivity test.

Molybdenum doses, according to Oliveira et al (2017), have no influence on agronomic characteristics. Nakao et al. (2014), testing four doses of leaf Mo found higher averages for plant height, number of pods per plant and number of seeds per pod, but there was no significant effect of Mo doses, a result that was also noticed in this work.

The results obtained for the variables shoot length and root length are shown in table 5 . As for shoot length, it is observed that in cultivar NS 5727 treatments 1, 2, 3 and 8 were the ones that stood out before other treatments. One of the factors responsible for the prominence in these treatments may have been the addition of Mo, in which it may have contributed to a greater physiological activity in the plant, making these treatments stand out before the control.

In cultivar DM 5859, it was noted that the control was superior to the other treatments, with no differences in the treatments to which they were submitted. This cultivar did not respond to the treatments applied. The cultivar NA 5909 showed better results in treatments 3 and 4 for the shoot length. The cultivar NS 5959, on the other hand, showed better results with treatments 5, 6, 9, and 10 when compared to the others. Ferreira et al (2018) found that the cultivar NA 5909 presents better performance in all evaluated characters when Mo and Co were applied. Werner et al (2020) verified that the application of Mo and Co positively influences soybean grain yield, with an average increase of about $20 \%$.

For the root length it is noted that the cultivar NS 5727 obtained the best result with treatments 8 and 9, comparing with the others. In cultivar DM 5958, little variation in root length occurred in the different treatments, with treatment 9 standing out. The cultivar 5909 reached the highest root lengths in treatments 2, 4, 5 and 6 in all cultivars analyzed. In NS 5959, the longest root length was found in treatment 3 seedlings in relation to the others. For the yield variable, the treatments did not show significant results in relation to the control. Table 6 shows the results obtained regarding yield due to applications of Mo and $\mathrm{K}$ in applications via leaf.

There were no significant differences for the yield of the soybean plants submitted to application of Mo and $\mathrm{K}$ in different doses and phenological stages as shown in table 6 . In general, several studies with micronutrients have not shown an answer. The justification is due to the fact that the soil would have sufficient capacity to supply the needs of the plant due to its origin and the constant presence of micronutrients in correctives and chemical fertilizers.

Agronomy Science and Biotechnology, Rec. 117, Volume 6, Pages 1-9, 2020 
Table 2. Means for interaction application times x cultivars, for variable germination, abnormal, hard, dead.

\begin{tabular}{|c|c|c|c|c|c|c|c|c|}
\hline \multirow{2}{*}{ Treatment } & \multicolumn{4}{|c|}{ Germination (\%) } & \multicolumn{4}{|c|}{ Abnormal (\%) } \\
\hline & 5727 & 5958 & 5909 & 5959 & 5727 & 5958 & 5909 & 5959 \\
\hline 1Mo V3 & $87.25 a b A B$ & $85.00 \mathrm{bB}$ & $86.25 \mathrm{bB}$ & $77.50 \mathrm{dC}$ & $9.50 \mathrm{cC}$ & $14.75 \mathrm{bB}$ & $13.50 \mathrm{aBC}$ & 20.25 aA \\
\hline 2 Mo R1 & 84.25 bcB & 90.25 aA & $91.00 \mathrm{abA}$ & $83.00 \mathrm{aB}$ & $15.00 \mathrm{aB}$ & $9.00 \mathrm{cC}$ & $8.75 \mathrm{bC}$ & $16.75 \mathrm{abAB}$ \\
\hline 3 Mo GF & 86.50 abcB & 83.25 bcB & 92.75 aA & $83.00 \mathrm{aB}$ & 11.75 abcBC & 15.75 bAB & $7.25 \mathrm{bC}$ & 15.75 bcAB \\
\hline 4 Mo V3 R1 & 83.50 bcB & 87.00 abB & $92.00 \mathrm{aA}$ & 84.00 abcB & 14.75 abB & $13.00 \mathrm{bcB}$ & $8.00 \mathrm{bC}$ & 15.25 bcAB \\
\hline 5 Mo V3 R1 GF & $87.75 a b B$ & $82.25 \mathrm{bcBC}$ & 93.25 aA & 83.50 abcB & 11.25 abcB & $17.00 \mathrm{abA}$ & $6.50 \mathrm{bC}$ & 15.25 bcAB \\
\hline $6 \mathrm{~K} \mathrm{R} 1$ & $81.75 c B$ & $85.50 \mathrm{abB}$ & $91.75 \mathrm{aA}$ & $85.00 \mathrm{aB}$ & $12.50 \mathrm{abcBC}$ & $14.00 \mathrm{bAB}$ & $8.25 \mathrm{bC}$ & $14.25 \mathrm{cAB}$ \\
\hline $7 \mathrm{KGF}$ & $88.75 a B$ & $86.75 a b B$ & 92.00 aAB & $84.00 a b c B$ & $8.50 \mathrm{cBC}$ & $13.00 \mathrm{bcB}$ & $7.50 \mathrm{bc}$ & 15.25 bcAB \\
\hline 8 Mo V3 K R1 & 83.00 bcB & $78.75 \quad c B$ & 92.75 aA & 80.00 abcdB & $14.75 \mathrm{abB}$ & $21.25 \mathrm{aAB}$ & $7.00 \mathrm{bC}$ & $19.00 \mathrm{abAB}$ \\
\hline 9 Mo V3 KR1 K GF & 84.00 bcB & 84.25 bAB & $90.50 a b A$ & $79.00 \mathrm{cdBC}$ & $14.25 \mathrm{abB}$ & $15.75 \mathrm{bB}$ & $8.50 \mathrm{bC}$ & $17.50 \mathrm{abcAB}$ \\
\hline 10 Mo V3 Mo GF K r1 K GF & 87.00 abB & 85.25 bB & 89.50 abAB & $79.50 \mathrm{cdC}$ & $10.25 \mathrm{bcBC}$ & $14.25 \mathrm{bB}$ & $8.50 \mathrm{bC}$ & 20.50 aAB \\
\hline Control & $90.00 \mathrm{aAB}$ & $85.00 \mathrm{bB}$ & $89.00 \mathrm{abAB}$ & $84.50 \mathrm{aB}$ & $8.00 \mathrm{cC}$ & $14.00 \mathrm{bB}$ & $8.00 \mathrm{bC}$ & $14.50 \mathrm{bcAB}$ \\
\hline CV (\%) & \multicolumn{4}{|c|}{4.09} & \multicolumn{4}{|c|}{21.28} \\
\hline \multirow{2}{*}{ Treatment } & \multicolumn{4}{|c|}{ Hard (\%) } & \multicolumn{4}{|c|}{ Dead (\%) } \\
\hline & 5727 & 5958 & 5909 & 5959 & 5727 & 5958 & 5909 & 5959 \\
\hline $1 \mathrm{Mo} \mathrm{V3}$ & $1.50 \mathrm{bA}$ & $0.00 \mathrm{aB}$ & $0.00 \mathrm{aB}$ & $0.00 \mathrm{aB}$ & $1.75 \mathrm{bcBC}$ & $0.25 \mathrm{aB}$ & $0.25 \mathrm{cB}$ & $2.25 \mathrm{abAB}$ \\
\hline 2 Mo R1 & $0.00 \mathrm{eA}$ & 0.00 aA & 0.00 aA & 0.00 aA & $0.75 \mathrm{cA}$ & 0.75 aA & $0.25 \mathrm{cA}$ & $0.25 \mathrm{cAB}$ \\
\hline 3 Mo GF & $0.75 \mathrm{cdA}$ & $0.00 \mathrm{aB}$ & $0.00 \mathrm{aB}$ & $0.00 \mathrm{aB}$ & $1.00 \mathrm{bcA}$ & $1.00 \mathrm{aA}$ & $0.00 \mathrm{cA}$ & $0.50 \mathrm{cA}$ \\
\hline 4 Mo V3 R1 & $0.75 \mathrm{cdA}$ & $0.00 \mathrm{aB}$ & $0.00 \mathrm{aB}$ & $0.00 a B$ & $1.00 \mathrm{bcA}$ & 0.00 aA & $0.00 \mathrm{cA}$ & $0.75 \mathrm{cA}$ \\
\hline 5 Mo V3 R1 GF & 0.00 eA & $0.00 \mathrm{aA}$ & 0.00 aA & $0.00 \mathrm{aA}$ & $1.00 \mathrm{bcA}$ & 0.75 aA & $0.25 \mathrm{cA}$ & $1.25 \mathrm{bcA}$ \\
\hline $6 \mathrm{~K} \mathrm{R} 1$ & $0.50 \mathrm{cdeA}$ & $0.00 \mathrm{aB}$ & $0.00 \mathrm{aB}$ & $0.00 \mathrm{aB}$ & $4.25 \mathrm{aAB}$ & $0.50 \mathrm{aB}$ & $0.00 \mathrm{cB}$ & $0.75 \mathrm{cB}$ \\
\hline $7 \mathrm{KGF}$ & $2.25 \mathrm{aA}$ & $0.00 \mathrm{aB}$ & $0.00 \mathrm{aB}$ & $0.00 \mathrm{aB}$ & $0.50 \mathrm{cA}$ & $0.25 \mathrm{aA}$ & $0.50 \mathrm{cA}$ & $0.75 \mathrm{cA}$ \\
\hline 8 Mo V3 K R1 & $1.25 \mathrm{bcA}$ & $0.00 \mathrm{aB}$ & $0.00 \mathrm{aB}$ & $0.00 \mathrm{aB}$ & $0.75 \mathrm{cA}$ & $0.50 \mathrm{aA}$ & $0.25 \mathrm{cA}$ & $0.75 \mathrm{cA}$ \\
\hline 9 Mo V3 KR1 K GF & $1.75 \mathrm{abA}$ & $0.00 \mathrm{aB}$ & $0.00 \mathrm{aB}$ & $0.00 a B$ & $0.50 \mathrm{cB}$ & $0.00 a B$ & $1.00 \mathrm{bcB}$ & $3.25 \mathrm{aAB}$ \\
\hline 10 Mo V3 Mo GF K r1 K GF & 0.50 cdeA & $0.00 \mathrm{aB}$ & $0.00 \mathrm{aB}$ & $0.00 \quad a B$ & $2.25 \mathrm{bA}$ & $0.50 \mathrm{aB}$ & $2.00 \mathrm{abA}$ & $0.00 \mathrm{cB}$ \\
\hline Control & $0.75 \mathrm{cdA}$ & $0.00 \mathrm{aB}$ & $0.00 \mathrm{aB}$ & $0.00 \mathrm{aB}$ & $1.25 \mathrm{bcB}$ & $1.00 \mathrm{aB}$ & $3.00 \mathrm{aA}$ & $1.00 \mathrm{bcB}$ \\
\hline CV (\%) & & & & & & & & \\
\hline
\end{tabular}

*Means followed by the lowercase letter in the column and uppercase letters in the row do not differ statistically by the Tukey test at $5 \%$ probability of error. 
Table 3. Means for interaction application times $\mathrm{x}$ cultivar for the variables abnormal seedlings and dead seeds in accelerated aging.

\begin{tabular}{|c|c|c|c|c|c|c|c|c|c|c|c|c|}
\hline \multirow{3}{*}{$\begin{array}{l}\text { Treatment } \\
1 \mathrm{Mo} \mathrm{V3}\end{array}$} & \multicolumn{6}{|c|}{ Abnormals of accelerated aging (\%) } & \multicolumn{6}{|c|}{ Dead of the accelerated aging (\%) } \\
\hline & \multicolumn{2}{|c|}{5727.00} & \multicolumn{2}{|c|}{5958.00} & 5909.00 & \multicolumn{2}{|c|}{5959.00} & \multicolumn{2}{|c|}{5727.00} & 5958.00 & 5909.00 & 5959.00 \\
\hline & 12.50 & $\mathrm{bcB}$ & 11.75 & $\mathrm{bcB}$ & $7.50 \mathrm{abBC}$ & 18.75 & bcA & 4.00 & $a b A$ & $0.75 \mathrm{bB}$ & $0.25 \mathrm{bBC}$ & 1.75 bcB \\
\hline 2 Mo R1 & 12.00 & $\mathrm{bcB}$ & 12.50 & $\mathrm{bcB}$ & $8.25 \mathrm{abBC}$ & 17.50 & $\mathrm{cA}$ & 2.00 & $\mathrm{cdB}$ & $1.25 \mathrm{abB}$ & $0.75 \mathrm{bB}$ & $2.50 \mathrm{bAB}$ \\
\hline 3 Mo GF & 14.00 & $\mathrm{bcB}$ & 11.00 & $\mathrm{CB}$ & $7.25 \mathrm{abBC}$ & 18.25 & $\mathrm{CAB}$ & 2.50 & bcA & $1.00 \mathrm{abAB}$ & $0.50 \mathrm{bB}$ & $1.75 \mathrm{bcAB}$ \\
\hline 4 Mo V3 R1 & 16.25 & $a b B$ & 12.25 & $b c B$ & $7.00 \mathrm{abC}$ & 17.75 & $\mathrm{CAB}$ & 1.25 & $\mathrm{~dB}$ & $1.25 \mathrm{abB}$ & $0.75 \mathrm{bB}$ & $1.75 \mathrm{bcAB}$ \\
\hline 5 Mo V3 R1 GF & 11.50 & $\mathrm{bcdB}$ & 14.00 & $a b c A c$ & $10.75 \mathrm{aBC}$ & 19.75 & $a b c A$ & 0.50 & $\mathrm{~dB}$ & $0.75 \mathrm{bB}$ & $0.50 \mathrm{bB}$ & 1.75 bcAB \\
\hline $6 \mathrm{~K} \mathrm{R} 1$ & 13.75 & $b c B$ & 11.50 & $\mathrm{bB}$ & $5.00 \mathrm{bc}$ & 19.75 & $a b c A$ & 4.50 & $a A$ & $1.50 \mathrm{abB}$ & $0.25 \mathrm{bB}$ & 0.75 bcAB \\
\hline $7 \mathrm{KGF}$ & 11.00 & $\mathrm{cdB}$ & 12.75 & $\mathrm{bB}$ & $7.00 \mathrm{abBC}$ & 19.00 & bcA & 2.50 & bcAB & $1.00 \mathrm{abB}$ & $0.00 \mathrm{bB}$ & $1.75 \mathrm{bcB}$ \\
\hline 8 Mo V3 K R1 & 14.50 & $a b c B$ & 16.25 & $a b B$ & $9.00 \mathrm{abBC}$ & 16.50 & $\mathrm{CAB}$ & 1.50 & $\mathrm{cdB}$ & $2.00 \mathrm{abAB}$ & $0.75 \mathrm{bB}$ & $0.50 \mathrm{cB}$ \\
\hline 9 Mo V3 KR1 K GF & 13.50 & $b c B$ & 18.50 & $a A B$ & $8.00 \mathrm{abBC}$ & 24.50 & $\mathrm{aA}$ & 0.25 & $\mathrm{~dB}$ & $2.75 \mathrm{aAB}$ & $1.50 \mathrm{bB}$ & $6.75 \mathrm{aA}$ \\
\hline 10 Mo V3 Mo EG K R1 K GF & 19.00 & $\mathrm{aB}$ & 16.50 & $a b B C$ & $6.00 \mathrm{abC}$ & 23.50 & $a b A B$ & 0.50 & $\mathrm{~dB}$ & $1.25 \mathrm{abB}$ & 3.50 aAB & $2.25 \mathrm{bB}$ \\
\hline Control & 7.00 & $\mathrm{dC}$ & 15.25 & $a b c B$ & $8.50 \mathrm{abC}$ & 18.50 & $\mathrm{CAB}$ & 0.75 & $\mathrm{cdB}$ & $0.50 \mathrm{bB}$ & $1.25 \mathrm{bAB}$ & $1.00 \mathrm{bB}$ \\
\hline CV (\%) & \multicolumn{7}{|c|}{26.02} & \multicolumn{5}{|c|}{25.03} \\
\hline
\end{tabular}

*Means followed by the lowercase letter in the column and uppercase letters in the row do not differ statistically by the Tukey test at $5 \%$ probability of error.

Table 4. Means for interaction application time x cultivar for variables in accelerated aging.

\begin{tabular}{|c|c|c|c|c|c|c|c|c|}
\hline \multirow{3}{*}{$\begin{array}{l}\text { Treatment } \\
1 \text { Mo V3 }\end{array}$} & \multicolumn{8}{|c|}{ Accelerated aging (\%) } \\
\hline & \multicolumn{2}{|c|}{5727} & \multicolumn{2}{|c|}{5958} & \multicolumn{2}{|c|}{5909} & \multicolumn{2}{|c|}{5959} \\
\hline & 82 & $\mathrm{bcB}$ & 87.5 & $\mathrm{aAB}$ & 92.25 & $a b A$ & 79.5 & $a B$ \\
\hline 2 Mo R1 & 84.75 & $\mathrm{bB}$ & 86.25 & $a b A B$ & 91 & $a b A$ & 80 & $a B$ \\
\hline 3 Mo GF & 81.75 & $\mathrm{bcB}$ & 88 & $\mathrm{aAB}$ & 92.25 & $a b A$ & 80 & $a B$ \\
\hline 4 Mo V3 R1 & 81 & $\mathrm{cB}$ & 86.5 & $a b A B$ & 92.25 & $a b A$ & 80.5 & $a B$ \\
\hline 5 Mo V3 R1 GF & 86.25 & $a b B$ & 85.25 & $a b B$ & 88.75 & $\mathrm{bAB}$ & 78.5 & $\mathrm{abC}$ \\
\hline $6 \mathrm{~K} \mathrm{R1}$ & 78.25 & $c B$ & 87 & $\mathrm{aAB}$ & 94.75 & $\mathrm{aA}$ & 79.5 & $\mathrm{aB}$ \\
\hline $7 \mathrm{KGF}$ & 85.25 & $\mathrm{aB}$ & 86.25 & $\mathrm{aAB}$ & 93 & $a b A$ & 79.25 & $a b C$ \\
\hline 8 Mo V3 K R1 & 82.75 & $b c B$ & 81.75 & $\mathrm{bcB}$ & 90.25 & $a b A$ & 81.5 & $\mathrm{aB}$ \\
\hline 9 Mo V3 KR1 K GF & 83.5 & $\mathrm{bB}$ & 78.75 & $\mathrm{cB}$ & 90.5 & $a b A$ & 68.75 & $\mathrm{cC}$ \\
\hline 10 Mo V3 Mo GF K R1 K GF & 78.75 & $\mathrm{CB}$ & 82.25 & $\mathrm{bcB}$ & 90 & $a b A$ & 74.25 & $\mathrm{bBC}$ \\
\hline Control & 90 & $\mathrm{aA}$ & 84.25 & $\mathrm{abB}$ & 90.25 & $a b A$ & 80.5 & $\mathrm{aB}$ \\
\hline CV (\%) & & & & & & & & \\
\hline
\end{tabular}

*Means followed by the lowercase letter in the column and uppercase letters in the row do not differ statistically by the Tukey test at $5 \%$ probability of error 
There were no significant differences for the yield of the soybean plants submitted to application of Mo and $\mathrm{K}$ in different doses and phenological stages as shown in table 6. In general, several studies with micronutrients have not shown an answer. The justification is due to the fact that the soil would have sufficient capacity to supply the needs of the plant due to its origin and the constant presence of micronutrients in correctives and chemical fertilizers.

Table 5. Means for interaction application times $x$ cultivars. for variable shoot length. root length.

\begin{tabular}{|c|c|c|c|c|c|c|c|c|c|c|c|c|}
\hline \multirow{3}{*}{$\begin{array}{c}\text { Treatment } \\
1 \text { Mo V3 }\end{array}$} & \multicolumn{8}{|c|}{ Shoot length $(\mathrm{cm})$} & \multicolumn{4}{|c|}{ Root length $(\mathrm{cm})$} \\
\hline & \multicolumn{2}{|c|}{5727} & \multicolumn{2}{|c|}{5958} & \multicolumn{2}{|c|}{5909} & \multicolumn{2}{|c|}{5959} & 5727 & 5958 & 5909 & 5959 \\
\hline & 10.64 & $a b c A$ & 6.87 & $\mathrm{dC}$ & 8.89 & $b B$ & 8.37 & $d B$ & $13.13 \mathrm{deBC}$ & $11.8 \mathrm{aC}$ & $14.36 \mathrm{deBC}$ & 14.72 abcdAB \\
\hline 2 Mo R1 & 11.34 & $\mathrm{aA}$ & 8.42 & $a b c d B$ & 8.04 & $c B$ & 8.94 & $\mathrm{bcdB}$ & $13.61 \mathrm{bcd} A \mathrm{~B}$ & $12.98 \mathrm{aBC}$ & 12.7 eBC & $13.32 \mathrm{cdBC}$ \\
\hline 3 Mo GF & 11.4 & $\mathrm{aAB}$ & 8.61 & $a b c d B C$ & 10.73 & $\mathrm{aAB}$ & 9.62 & $b c d B$ & 14.75 abcBC & $12.98 \mathrm{aC}$ & $16.07 \mathrm{abcAB}$ & $15.98 \mathrm{Abc}$ \\
\hline 4 Mo V3 R1 & 10.02 & $a b c d B$ & 7.86 & bcdC & 11.01 & $a A B$ & 10.24 & $b c B$ & $14.25 \mathrm{aBC}$ & $13.01 \mathrm{aC}$ & $16.39 \mathrm{abAB}$ & $14.27 \mathrm{bcdBC}$ \\
\hline 5 Mo V3 R1 GF & 8.68 & $\mathrm{bcdB}$ & 7.94 & $\mathrm{bcdBC}$ & 10.00 & $a b A$ & 10.88 & $a b A$ & 14.57 abcdBC & $12.53 \mathrm{aC}$ & 16.1 abcAB & 14.7 abcdBC \\
\hline $6 \mathrm{~K} \mathrm{R} 1$ & 9.21 & $\mathrm{cdB}$ & 7.18 & $\mathrm{cdBC}$ & 10.94 & $\mathrm{aAB}$ & 11.64 & $a b A$ & $11.64 \mathrm{eC}$ & $12.47 \mathrm{aBC}$ & $17.38 \mathrm{abAB}$ & 15.15 abBC \\
\hline $7 \mathrm{KGF}$ & 9.66 & bcdAB & 7.63 & $\mathrm{bcdBC}$ & 7.32 & $\mathrm{cC}$ & 10.05 & bcA & 13.11 cdeBC & $11.92 \mathrm{aC}$ & $13.09 \mathrm{eBC}$ & 14.86 abcA \\
\hline 8 Mo V3 K R1 & 10.82 & $a b A B$ & 8.74 & $a b C$ & 10.69 & $\mathrm{aBC}$ & 8.79 & bcdC & 15.25 abcAB & $12.53 \mathrm{aC}$ & 15.13 bcdAB & $13.07 \mathrm{Dbc}$ \\
\hline 9 Mo V3 KR1 K GF & 9.88 & $a b c d B C$ & 8.26 & bcdC & 10.04 & $a b A B$ & 10.43 & $a b c A B$ & $15.37 \mathrm{aBC}$ & $13.3 \mathrm{aC}$ & 15.68 bcdAB & 14.29 abcdBC \\
\hline 10 Mo V3 Mo GF K R1 K GF & 9.22 & $\mathrm{cdB}$ & 8.37 & $a b c d B C$ & 9.19 & $\mathrm{bBC}$ & 11.15 & $a b c A$ & $13.73 \mathrm{aBC}$ & $12.98 \mathrm{aC}$ & $13.88 \mathrm{eBC}$ & 14.65 abcdAB \\
\hline Control & 8.86 & $\mathrm{dC}$ & 9.88 & $\mathrm{aBC}$ & 9.97 & $\mathrm{abBC}$ & 10.14 & $\mathrm{bAB}$ & 13.1 cdeBC & $13.07 \mathrm{aC}$ & $14.41 \mathrm{cdBC}$ & 15.19 abAB \\
\hline CV (\%) & & & & 24.3 & & & & & & 27. & & \\
\hline
\end{tabular}

*Means followed by the lowercase letter in the column and uppercase letters in the row do not differ statistically by the Tukey test at 5\% probability of error

Table 6. Values of average seed yield (Kg-Ha') as a function of Mo and $\mathrm{K}$ doses applied via leaf.

\begin{tabular}{c|c}
\hline Cultivars & Yields (Kg) \\
\hline NS 5727 IPRO & $3023.93 \mathrm{a}$ \\
NS 5959 IPRO & $3118.33 \mathrm{a}$ \\
NA 5909 RG & $3115.6 \mathrm{a}$ \\
DM 5958 IPRO & $3233.48 \mathrm{a}$ \\
\hline CV (\%) & $\mathbf{8 . 9 2}$ \\
\hline
\end{tabular}


When working with methods of applying Mo to soybean, Adesoji, Abubakar and Ishaya (2009), found no significant difference between the methods. However, the foliar application of a commercial product containing cobalt and molybdenum up to a dose of $240 \mathrm{~mL} / \mathrm{ha}^{-1}$ positively affects the number of seeds per pod of the crop. For the variables yield and 100 grain mass, Nakao et al (2014) found significant differences with the use of molybdenum, being possible the addition of $486 \mathrm{~kg} \mathrm{ha}^{-1}$ with the use of $800 \mathrm{~g} \mathrm{ha}^{-1}$ of molybdenum.

On the other hand, Possenti and Villela (2010), studying the effect of molybdenum via leaf feeding and seeds on soybeans, did not obtain significant differences in grain yield between the adopted treatments and the control. According to Diesel, Silva, Silva and Nolla (2010) to the mobility that Mo exerts in the plant, it can be added in solutions via foliar fertilization, because in this way, its absorption occurs quickly, without the risk of decreasing display when added to the soil.

\section{CONCLUSIONS}

In this study, there is influence of foliar feeding of molybdenum (Mo) and potassium (K) in different phenological stages of soybean. It was found that there was no significant difference for the yield of soybean cultivars under foliar feeding of $\mathrm{Mo}$ and $\mathrm{K}$ in the different treatments to which they were submitted.

\section{REFERENCES}

Adesoji, A. G., Abubakar, I. U., \& Ishaya, D. B. (2009). Performance of Soybean (Glycine max(L.) Merrill) as influenced by Method and Rate \nof Molybdenum Application in Samaru, Northern Guinea Savanna of Nigeria. American-Eurasian Journal of Sustainable Agriculture., 3(4)(1995-0748), 845-849. Retrieved from http://www.aensionline.com/aejsa/2009/845-849

Broadley, M., Brown, P., Cakmak, I., Rengel, Z., \& Zhao, F. (2011). Function of Nutrients: Micronutrients. In H. Marschner (Ed.), Marschner's Mineral Nutrition of Higher Plants (3rd ed., pp. 191-248). Academic Press.

CONAB - Companhia Nacional de Abastecimento. (2018). Boletim grãos setembro 2018. Retrieved from https://www.conab.gov.br/info-agro/safras/graos/boletim-da-safra-de-

graos/item/download/22227_378630c35e68682d6a984ecbd43bfe1d

Diesel, P., Silva, C. A. T., Silva, T. R. B., \& Nolla, A. (2010). Molibdênio e cobalto no desenvolvimento da cultura da soja Molybdenum. Revista Agrarian, 3(8), 169-174.

Fehr, W. R., \& Caviness, C. E. (1977). Stage of soybean development (Special Re). Ames: lowa State University. Retrieved from http://lib.dr.iastate.edu/specialreports/87

Felisberto, G., Bruzi, A. T., Zuffo, A. M., Zambiazzi, E. V., Soares, I. O., Rezende, P. M., \& Botelho, F. B. S. (2015). Agronomic performance of RR soybean cultivars using different pre-sowing desiccation periods and distinct post-emergence herbicides. African Journal of Agricultural Research, 10(34), 3445-3452. https://doi.org/10.5897/ajar2015.9853

Ferreira, A. G., Santos, W. P., Martins, J. K. D., Bravin, N. P., Siqueira, M. G., \& Machado, C. B. (2018). Desempenho agronômico de cultivares de soja em função de diferentes métodos de aplicação de cobalto e molibdênio. Cultivando o Saber, 11(2), 11-19.

Korber, A. H. C., Pinto, L. P., Pivetta, L. A., Albrecht, L. P., \& Frigo, K. D. A. (2017). Adubação Nitrogenada E Potássica Em Soja Sob Sistemas De Semeadura. Journal of Neotropical Agriculture, 4(4), 38-45. https://doi.org/10.32404/rean.v4i4.1653

Matsumoto, L. S., Santos, I. M. O., Barazetti, A. R., Simões, G. C., Farias, T. N., \& Andrade, G. (2017). Effects of biological control agents on arbuscular mycorrhiza fungi Rhizophagus clarus in soybean rhizosphere. Agronomy Science and Biotechnology, 3(1), 29. https://doi.org/10.33158/asb.2017v3i1p29 
Meneghette, H. H. A., Lazarini, E., Bossolani, J. W., Santos, F. L., \& Sanches, I. R., Biazi, N. Q. (2019). Adubação potássica em plantas de coberturas no sistema de plantio direto e efeitos na cultura da soja em sucessão. Colloquium Agrariae, 15(3), 1-12. https://doi.org/10.5747/ca.2019.v15.n3.a294

Nakao, A. H., Vazquez, G. H., Oliveira, C., Silva, C., Fernando, M., Souza, P., ... Solteira, I. (2014). APLICAÇÃO FOLIAR DE MOLIBDÊNIO EM SOJA: EFEITOS NA PRODUTIVIDADE E QUALIDADE FISIOLÓGICA DA SEMENTE. Enciclopédia Biosfera, 10(18), 352.

Oliveira, C. O., Pinto, C. C., Garcia, A., Bettiol, J. V. T., de Sá, M. E., \& Lazarini, E. (2017). Produção de sementes de soja enriquecidas com molibdênio. Revista Ceres, 64(3), 282-290. https://doi.org/10.1590/0034-737X201764030009

Possenti, J. C., \& Villela, F. A. (2010). Efeito do molibdênio aplicado via foliar e via sementes sobre o potencial fisiológico e produtividade de sementes de soja. Revista Brasileira de Sementes, 32(4), 143150. https://doi.org/10.1590/s0101-31222010000400016

Santinoni, I., Santos, I., Niekawa, E., Dealis, M., Liuti, G., Silva, C., ... Andrade, G. (2019). Effect of transgenic soybean on functional groups of microorganisms in the rhizosphere in soil microcosm. Agronomy Science and Biotechnology, 5(1), 11. https://doi.org/10.33158/asb.2019v5i1p11

Serafim, M. E., Ono, F. B., Zeviani, W. M., Novelino, J. O., \& Silva, J. V. (2012). Soil moisture and potassium doses on soybean culture. Revista Ciencia Agronomica, 43(2), 222-227. https://doi.org/10.1590/s180666902012000200003

Soares, I. O., Rezende, P. M., Bruzi, A. T., Zuffo, A. M., Zambiazzi, E. V., Fronza, V., \& Teixeira, C. M. (2015). Interaction between Soybean Cultivars and Seed Density. American Journal of Plant Sciences, 06(09), 1425-1434. https://doi.org/10.4236/ajps.2015.69142

Struker, S., Carvalho, I. R., Szareski, V. J., Barbosa, M. H., Souza, V. Q. de, Conte, G. G., ... Pedó, T. (2019). Influence of seeds vigor in the attributes of soybean yield. Revista de Ciências Agrárias, 42(3), 111-120. https://doi.org/10.19084/rca.16389

Taiz, L., \& Zeiger, E. (2012). Fisiologia Vegetal (4th ed.). Porto Alegre, RS: ArtMed.

Toledo, M. Z., Castro, G. S. A., Crusciol, C. A. C., Soratto, R. P., Nakagawa, J., \& Cavariani, C. (2011). Physiological quality of soybean and wheat seeds produced with alternative potassium sources. Revista Brasileira de Sementes, 33(2), 363-371. https://doi.org/10.1590/s0101-31222011000200019

Veiga, A. D., Pinho, É. V. R. Von, Veiga, A. D., Pereira, P. H. A. R., Oliveira, K. C., \& Pinho, R. G. Von. (2010). Influência do potássio e da calagem na composição química, qualidade fisiológica e na atividade enzimática de sementes de soja. Ciência e Agrotecnologia, 34(4), 953-960. https://doi.org/10.1590/s1413-70542010000400022

Werner, H. A., Esteves, M. P. C., Lima, B. M., Valcácio, T. L., Castro, W. C. P., Barros, S. C. S., Pamplona, V. M. S., Quadros, B. R. (2020). Physiological quality of soybean (Glicyne max L. Merrill) seeds treated with micronutrients Calidad. Research, Society and Development, 9(9), 1-13.

Received: January 20, 2021.

Accepted: March 9, 2021.

Published: March 31, 2021.

\section{English by: Francine Lautenchleger}

